\title{
Orhan BİNGÖL
}

\author{
Dr. Öğr. Üyesi \\ Gümüşhane Üniversitesi, Edebiyat Fakültesi Sosyoloji Bölümü, Gümüşhane -TÜRKİYE \\ Gümüşhane University, Faculty of Letters, Department of Sociology, Gümüşhane -TURKEY \\ ORCID: 0000-0003-4398-3548 \\ orhanbingol@gumushane.edu.tr
}

\section{Yıldönümünde İnsan Haklarını Yeniden Düşünmek}

\section{Öz}

İnsan, hemen her bilimin, sanatın, felsefenin ya da dinin ortak paydalarındandır. Çünkü insan, düşüncesiyle, bilgisiyle, tasarımcılığıyla ve inancıyla bu alanların hepsinde aktif olarak yer almaktadır. $\mathrm{Bu}$ muazzam yaratıcılığın ilhamıyla insan, kendine birtakım öncelikler tanımıştır. Söz konusu ayrıcalıkların başında insan hakları da bulunmaktadır.

İnsan hakları, temelde, insanın kendini özel, önemli ve korunaklı kılmasını vurgulamaktadır. Alanın en çekişmeli taraflarından biri ise bu konudaki ideallerle realitenin çarpışıyor olmasıdır. Bu ikilem insan haklarının geçerliliğini tartışmaya açmaktadır. Çünkü insan şayet haklarını yaşayabildiği ölçüde insansa; hakları tam olarak gerçekleşemediğinde onun insani ve sosyal varlığına da savaş açılmıș olmaktadır.

En az bunun kadar çarpıcı olan bir başka nokta, insana bunu yine kendinin yaptığıdır. İnsan, haklarını bir kalkan olarak aslında yine ya kendine ya da kendi var ettiği toplum ve devlet gibi yapılara karş1 kullanmaktadır. Bütün bunlara göre insan hakları, öteden beri olduğu gibi bugün de kritik ve vazgeçilmez sorunsalların başında bulunmaktadır. Dolayısıyla bu makale, ilanının 70. yıl dönümünde insan haklarını yeniden düşünmeye davet eden bir derleme olarak kaleme alınmıştır.

Anahtar Kelimeler: İnsan, Hak, İnsan Hakları, Demokrasi, Devlet.

\section{Rethinking Human Rights on the $70^{\text {th }}$ Anniversary}

\begin{abstract}
Human is one of the common grounds of almost every science, art, philosophy or religion. Because human actively takes part in all of these areas with his/her thoughts, knowledge, design and belief. With inspiration of this enormous creativity, human has given himself/herself a number of priorities. Human rights are also at the top of these privileges.

Human rights essentially emphasize that human makes himself/herself special, important and sheltered. One of the most contentious aspects of the field is that the ideals on this issue collide with reality. This dilemma opens the question of the validity of human rights. Because if human being is human as long as he/she lives his/her rights, when they are not fully realized, war against his/her human and social existence has been waged.

Another point at least as striking as this is that human does this to himself/herself again. Human uses his rights as a shield against himself/herself or the structures such as society and the state which is created by himself/herself. According to all these, human rights have been at the head of critical and indispensable problems from yesterday to today. Therefore, this article is written as a compilation that invites people to rethink human rights on the 70th anniversary of its announcement.
\end{abstract}




\section{Orhan BİNGÖL, “70. Yıldönümünde İnsan Haklarını Yeniden Düşünmek”,}

Mavi Atlas, 6(Özel Sayı)/2018: 63-76.

Keywords: Human, Right, Human Rights, Democracy, State.

\section{İnsan ve İnsan Doğası Üzerine}

İnsan, yüzyıllardan bu yana birike gelmiş kültürel ve tarihi ilerleyişin sahibidir. İnsan aynı zamanda bu birikimin konusunu da teşkil etmektedir. Böyle yaklaşıldığında toplum ve tarih, insanın kendini yazdığı ve yaşadığı alanları oluşturmaktadır. İnsanın bu çok yönlülüğ̈̈ onun ayırt edici bazı niteliklerine, özellikle de aklına ve toplumsallığına dayanmaktadır. Öyle ki insan, yaşayan canlılar içerisinde en akıllı ve en sosyal olanıdır.

Akıl, insana en başta hem kendini hem de tüm dünyayı fark etmenin temel dayanağını sunmaktadır. Ve pek çok gelişme, bu büyük farkındalıkla birlikte hızlanmaktadır. Söz konusu ilerlemelerin çıkış noktası aklı kullanmaktır. Böyle bakıldığında "akıl, önce doğayı sonra da insanı kullanır" (Çeçen 1995: 22). Başka türlü söylenirse akıl, hemen her şeyi bilmenin, anlamanın ve de kontrol etmenin esas anahtarlarındandır. İște akıllı insan ya da aklını kullanan insan doğadan ve doğada yaşayanlardan radikal olarak böyle ayrılmaktadır.

İnsanın doğadan kopuşu, akıl değişkeninden kalkarak daha geniş açılımlara ulaşmaktadır. Bu noktada insanın kendi ürettiği özgün ve karmaşık doğası ile kendi dışındaki doğanın arasındaki farklar dikkate değerdir. Söz konusu ayrılığa göre doğal oluşun temel özelliği kendiliğindenliktir. Yani doğada genel bir düzenlilik vardır ama geleceğe doğru amaçlı bir yönlenme ya da yönlendirilme yoktur. Doğa kendiliğinden düzenli fakat amaçsızdır. İnsan oluşta ise kendini doğaya bırakmanın tersine bir süreç söz konusudur. İnsan, kendini doğaya uyarlamaktan ziyade doğayı kendine adapte etmektedir (Nutku 2002: 180, 181). Çünkü insan kültürle üremekte ve kültür üretmektedir. Bu açıdan insanın kendine özgü doğası, kültürel oluşla eş anlamlıdır. Öyleyse “...insan doğası, önceden belirlenmiş bir özü yansıtmaktan çok, insanın tarihinin ve deneyimlerinin bir sonucudur" (Marshall 2003: 341-342).

İnsanın bu özelliği, içinde yaşadığı doğa ile arasındaki yapısal ayrılığın gittikçe büyümesine neden olmuştur. Öyle ki insan en başından bu yana doğayla zıtlaşan kültürel uca konumlanmıştır. Bu pozisyonundan hareketle insan, doğadan ve doğal oluştan gittikçe uzaklaştığı gibi kendini ve doğayı kültüre daha çok yaklaştırmıştır. Ve bu insani gelişim çerçevesinde ortaya çıkan tarih, bir kültür tarihi olarak birikmiştir. Diğer deyişle kaydedilmiş tarih, insanın ürettiği kültür(ler)den meydana gelmiştir. 


\section{Orhan BİNGÖL, "70. Yıldönümünde İnsan Haklarını Yeniden Düşünmek”, \\ Mavi Atlas, 6(Özel Sayı)/2018: 63-76.}

Ne var ki insanın bir niteliği, tarih boyunca nerdeyse hiç değişmemiştir: İnsan bilinen zaman ve mekânların hemen hepsinde sosyal bir yaşam sergilemiştir. Kaldı ki sosyal yaşam, kültürel doğası göz önüne alındığında insan için en uygun olan yaşam biçimi gibidir. Çünkü sosyal hayat yalnız yaşamaktan çok daha farklı ve ileridir. Sosyal yaşamla beraber insan hayatına kaçınılmaz olarak değerler, normlar, yaptırımlar, ödüller, cezalar, çatışmalar ya da uzlaşmalar eklenmektedir. Zaten bu sayılanların hepsi toplumsal yaşam dâhilinde anlam edinmektedir. Bunlar aynı zamanda insanın sosyal hayata hazırlanmasını, sosyal hayatı deneyimlemesini yani toplumsallaşmasını gerçekleştirmektedir.

$\mathrm{Bu}$ doğrultudan devam edildiğinde sonunda topluma ve toplumsal yaşama ulaşılmaktadır. Toplum, insanın geliştirdiği sosyal sistemlerin en büyüğü olarak tüm insani/kültürel ürünlerin birbirine geçmesinden oluşmaktadır. Bu noktada, insan ve toplum etkileşimlerini ele alan yaklaşımlardan ikisine kısaca değinilebilir. Bunların ilkine göre toplum, temelde insanın menfaatlerine yönelik işlevsel bir gerçekliktir. Yani "toplum, insanların paylaştıkları sorunları birlikte çözme çabalarının bir ürünüdür" (Erol 2008: 6). O halde insanın kendini korumak istediği veya kendi kendine yetemediği hallerde devreye toplum girmektedir.

İnsan ve toplum ilişkilerine eğilen diğer büyük perspektife göreyse toplum, birçok problemin doğduğu yerdir. Toplum, sorunların birlikte çözülmeye çalışılması kadar sorunların bizzat üretildiği bir yapıyı da resmetmektedir. Çünkü toplum halinde yaşamak pek çok eşitsizliğin, çelişkinin, çifte standardın ya da çatışmanın önünü açmaktadır.

Bütün bunlara rağmen toplumsal yaşam denen göreli denge dünden bugüne kendini korumayı başarmıştır. İnsanlar, tüm benzerlikleri ve farklılıklarıyla, dezavantajları ve avantajlarıyla bir arada, toplum halinde yaşamışlardır. Zaten insanın bundan başka bir alternatifi yok sayılır. Başta bu zorunlu sebebin de etkisiyle insan, toplumsal yaşamın olanaklı olması ve var kalması için birtakım dayanaklar üretmiştir. İşte "hak"lar, bunların en önemlilerinden biridir. Haklar, insanın kendi yarattığı ve kendini yarattığı toplumsal dünyayı bir arada tutmaya çalışan başlıca öğelerdendir.

\section{Hak Kavramı}

Hak ve/veya haklar konusu derin bir kapsama, köklü bir tarihe sahiptir. Öyle ki hakkın tanımı, biçimleri, değişken ve sabit yönleri, sınırları veya hakların hangi yollarla korunup geliştirilebileceği yüzyıllardır tartışıla gelmiştir. Haklara ilişkin bu 


\section{Orhan BİNGÖL, "70. Yıldönümünde İnsan Haklarını Yeniden Düşünmek”, Mavi Atlas, 6(Özel Sayı)/2018: 63-76.}

tartışmaların genelde birbirinden farklı noktalara işaret ettiği ama kimi ortak zeminlerde birleşebildiği de görülmektedir. Hakların çerçevelendiği bu üst başlıkların içerisinde insan, toplum ve devlet en büyükleridir.

Buradan yola çıkarak hakları önce insan ölçütünde ele alan görüşlere bakılabilir. Söz konusu açıklamalara göre insanın hakları ya da temel hakları, onun öncelikle insan oluşundan ileri gelmektedir. Bu açıdan "temel haklar... insan olma değerini ve onurunu koruyan ve geliştiren haklardır" (Çüçen 2011: 77). Diğer ifadeyle insanı var eden ve ilerleten haklar, onun varlığından doğan en temel haklardır. Bu hakların neler olduğu hayli uzun bir listeye yayılmaktadır. Fakat söz gelimi Rousseau, temel haklar listesinin kendince kısa ve kesin bir karşılığını yüzyıllar öncesinde yazmıştır: Rousseau'ya göre "her kimsenin, kendisi için zorunlu olan her şey üzerinde doğal bir hakkı vardır" (2013: 23).

Bu noktada insanın temel haklarını değerlendiren alanların başında etiğin geldiği söylenebilir. Çünkü insan, kendi türüne ait bir ahlak dünyasını inşa edip bunun içerisinde gelişen tek memelidir. Etik ise bunun evrensel boyutlarını incelemektedir. Bu yüzden insan, kendi özgül yapısı gereği (en azından teoride) bazı temel hakların zaten sahibidir. Diğer cümlelerle, bu konudaki “...yaygın anlayışa göre... insan olmak bu haklara sahip olmak için yeterlidir” (Yeşilçayır 2018: 243). Böyle bakıldığında temel haklar, bütün insanların bu haklara yaraşır olduğunun kanıtları gibidir.

İnsan ve hakları konusunu yorumlayan öteki bakış açısı, görüşlerini topluma çevirmektedir. Buna göre haklar sadece insani boyutla değil, toplumsal ölçekle de değerlendirilmelidir. Çünkü her insan, insan oluşu sebebiyle hak sahibi olduğundan temel haklar da herkes içindir. Beraberinde, bu genellemenin mutlaka toplumsal yaşam çerçevesinde yapılması gerekir. Öyle ki insanlar sosyal yaşamı hep birlikte tecrübe etmektedir.

Ancak düşüncede sorunsuz görünen bu zincir, pratikte birtakım sorunlar ve kırılmalarla yüzleşmektedir. Bunun ironik sebebi hakların yine toplum içerisinde kullanıldığında sosyalleşebilmesiyle ilgilidir. Diğer bir anlatımla, insani hakların değeri ve işlevleri en çok da toplumsal dünyada gerçeklik edinmektedir. Bu durum hakların kullanımı hususunda öteki insanlarla karşılaşmak, dolayısıyla haklara bazı kısıtlamalar getirmek anlamına gelir. O halde her insan kendine ve aynı zamanda diğerlerine karşı haklıysa, bunun düzenlenmesi nasıl gerçekleşecektir?

Böyle bir soru(n)dan devam edildiğinde hak, bireylerin toplumdan isteyebilecekleri ve bunu toplum içerisinde kullanabilecekleri yetkiler biçimine 


\section{Orhan BİNGÖL, "70. Yıldönümünde İnsan Haklarını Yeniden Düşünmek”, Mavi Atlas, 6(Özel Sayı)/2018: 63-76.}

dönüşmektedir (Çüçen 2011: 44). Buna göre haklar bireysel olduğu kadar toplumsal karakterlere de sahiptir. Haklara böyle bir toplumsal öncelik tanımanın bazı gerekçeleri söz konusudur. Örneğin toplum, yapısı gereği insandan daha güçlü ve çok daha uzun ömürlüdür. Bu nedenle toplum, hakları tanımak ya da insanlara dağıtmak gibi yapısal bir ayrıcalığı elinde bulundurur. Öte yandan toplum, insanın içinde var olduğu ve olacağı biricik adrestir. İnsanın toplumsal yaşamın dişında haklarını isteyebileceği veya kullanabileceği başka bir yaşam alanı yok gibidir. Bu tür nedenlerle toplum, hakların verilmesi, sınırlandırılması ve haklardan yararlanılması noktalarında kendi çapında geçerli dayanaklara sahiptir. Ancak toplumların haklar konusunda ne kadar eşitlikçi, şeffaf ve yapıcı olup olmadığı elbette değişkenlik göstermektedir

Hakların açılımında insan ve toplum başlıklarının yanı sıra devlet de ciddi bir taban teşkil etmektedir. Hakları devletle beraber ele almak aslında yeni bir şey değildir. Düşünce tarihi bunun örnekleri açısından oldukça zengindir. Söz gelimi Hegel, bunlardan biridir. Hakları özellikle özgürlük ve devletle birlikte değerlendiren Hegel'e göre insanın koruması gereken en önemli haklarının başında özgürlük gelmektedir. Ona göre insanın kendi özgürlük hakkını koruması, başkalarının özgürlüğüne saygılı olmasıyla zorunlu bir ilişki içerisindedir. Hegel'de bu zorunluluğu resmileştiren tarafsa hukuk ve devlettir. Yani Hegel için başta özgürlük olmak üzere insanın çeşitli hakları, hukukun ve devletin güvencesi altındadır. Haklar konusunu düşünenler arasında Hobbes da bulunmaktadır. Hegel gibi Hobbes da nelerin hak olup olmadığının tespitini devlete bırakmıştır (Hançerlioğlu 1977/Cilt 2: 275).

Bu gibi söylemlere bakıldığında devlet, hakların tanımlanması ve yasal olarak sınırlandırılması aşamalarında en üst birimi temsil etmektedir. Zaten devletin varlık nedenlerinden biri de insan, toplum ve hak üçlüsünün mümkünlüğünü üstlenmek veya buna bir ciddiyet getirmek değil midir? Öyle ki haklar devletin kendi gücünü göstermesi ya da pekiştirmesine yaradığı kadar (belki bundan çok) devletin meşru ve kabul edilebilir zeminlerden birine oturmasına da yardım etmektedir. Aksi halde belki de "haksızlığın, adaletsizliğin olmadığı bir yerde kimse devleti düşünmeyecektir" (Schopenhauer 2010: 85).

Fakat birbirinden farklı toplumlar için geçerli olduğu gibi çeşitli devletlerin de haklar konusundaki adaletinin ve hassasiyetinin bir örnek olmadığını unutmamak gerekir. Bu noktada hak ve devlet ilişkisine bir yorum da eklenebilir: Haklar üzerinde özellikle modern dönemle birlikte devletin payının gittikçe küçülmesinin arzu edildiği 


\section{Orhan BİNGÖL, "70. Yıldönümünde İnsan Haklarını Yeniden Düşünmek”, Mavi Atlas, 6(Özel Sayı)/2018: 63-76.}

ve beklendiği görülmektedir. Buna göre haklar hususunda devlet kadar bireysel otokontrollerin ve meşru toplumsal iradenin de söz sahibi olması gerektiği yönündeki ses gittikçe yükselmektedir.

\section{İnsan Haklarını Tanımlamak}

İnsan hakları, esasında temel haklarla ve onların nitelikleriyle eş doğrultuda sayılır. Temel haklar gibi insan haklarının da örneğin toplum ve devletle organik bağları bulunmaktadır. İnsan hakları aynı zamanda insanın diğer bireylerle ilişkilerine de dokunmaktadır. Bu anlamda örneğin Schopenhauer'a göre özellikle bireysel açıdan bakıldığında "insan haklarını tanımlamak kolaydır; herkes kimseye zarar vermeyen her şeyi yapma hakkına sahiptir"' (2010: 84).

Öte yandan, temel hakların yansıttı̆ğ liste ile insan haklarının olmazsa olmaz maddeleri de hemen hemen aynı paraleldedir. Bu maddelerin ilk sıralarında yaşama, güvenlik, eğitim, inanma, seçme ve seçilme, özgürlük ve ifade özgürlüğü hakları gelmektedir. Bu ve benzeri maddeler, özellikle modernleşmenin getirdiği paradigmaya göre istisnasız herkes için geçerlilik göstermelidir. Dolayısıyla insan hakları, temel hakların hem özel bir ismi hem de bu hakların tüm insanlara genellenmesi şeklinde düşünülebilir.

İnsan haklarının temel karakterine bakıldığındaysa bu hakların bazı değişmez yönlere sahip olduğu görülmektedir. İnsan haklarının evrenselliği, yok edilemezliği, kısıtlanamazlığı, vazgeçilemez veya başkalarına devredilemezliği söz konusu özelliklerin başlıcalarındandır (Çüçen 2011: 49, 50). Böylelikle insan hakları, insani ve toplumsal yönlerin yanı sıra hukuki ve siyasal boyutlara da yayılmaktadır. Zaten insan hakları, bu çok boyutluluğu nedeniyle zaman içerisinde sürekli kendini aramış ve tamamlamaya uğraşmıştır. Hem nicelik hem de niteliğe dönük bu ilerleyiş daima daha iyiye varmaya çalışmıştır. Böyle alındığında insan hakları, geçmişi ve şimdisiyle, kendi içinde ve disiplinler arası düzeyiyle büyük bir önem taşımaktadır. Bu çerçevede "insan haklarının sayısının belirli olmaması, hemen her dönemde yeni yeni insan haklarının ortaya çıkması..., hakların toplumlara göre gelişmeler göstermesi, ...eski ve yeni haklar arasındaki ilişkiler ve hakların hukuk alanındaki değişmelerden etkilenmeleri konunun önemini daha da artırmaktadır" (Çeçen 1995: 19). Nitekim insan haklarının geçirdiği tarihsel süreç bu önemi açıkça doğrulamaktadır.

\section{İnsan Haklarının Hızlı Tarihçesi}


İnsan haklarının ciddi ilk tarihi Eski Yunan Uygarlı̆̆ı'na kadar götürülmektedir. Örneğin Sofistler, insana verdikleri değerle insan haklarının kıymetini ilk vurgulayan düşünürlerdendir. Öyle ki Sofistlerle birlikte çeşitli felsefi görüşler ve problemler doğadan insana doğru çevrilmiştir. Çünkü Sofistler, insanların daha rahat, huzurlu ve mutlu yaşamaları için yeteneklerinin geliştirilmesi gerektiğini söylemişlerdir (Çüçen 2011: 37). Sofistlerin bu söylemi, insanın sahip olduğu öz değerin öncelikle yine kendisi tarafindan teslim alınması gerektiği şeklinde yorumlanabilir. Bu çıkış, insanın, hakları konusunda da kendinden sorumlu bir otorite oluşunun, olması gerektiğinin ilk işaretlerindendir.

İnsan haklarının gelişiminde diğer büyük ilerleme olarak Magna Carta gösterilmektedir. 1215'te İngiltere'de ilan edilen Magna Carta ile insan haklarının en çok da hukuki boyutunun altı çizilmiştir. Magna Carta, insan hakları içerisinde daha çok özgürlük ve yasalar önündeki eşitlik noktalarına dikkat çekmiştir. Belgede geçen "hiç kimsenin kanuna uygun olmayan şekillerde tevkif edilemeyeceğine, hapsedilemeyeceğine ya da sürgüne gönderilemeyeceğine" dair maddeler bunu direkt belirtmektedir (Çüçen 2011: 37, 38). Dönemin mevcut siyasal toplu durumu ve din kurumunun o yıllardaki gücü göz önünde alınırsa, Magna Carta'nın insan haklarını özellikle bu ikisine karş1 güçlendirmeye çalıştığ 1 söylenebilir.

Takip eden tarihi dilimde Batı ve Ortaçağ ikilisi kendini göstermektedir. $\mathrm{Bu}$ evrede özellikle Ortaçağ Batısı'nın insan ve hakları konusunda olumsuzluklar kaydettiği bilinmektedir. Çünkü bu çağda insan hakları kilisenin sarsılmaz egemenliği altında adeta aşınmıştır. Temel haklarını kilisenin lüksünde yaşamaya çalışan Avrupalı insan, bu dönemden pek çok yaptırımla, yasakla, cezayla ve hatta ölümle ayrılmıştır.

Diğer taraftan Orta Çă̆'da yaşanan negatif tecrübelerin, uzun vadede, eskinin tam ters tersine gelişmelere zemin hazırladığ 1 da öne sürülebilir. Öyle ki Orta Çağ' da Batı'ya hükmeden en büyük güçlerden biri dindir. Din, bu süreçte devlet üzerinde de etkindir. Bu nedenle "din olgusunun giderek ön plana geçmesi ve dinsel ilkelerin devlet yönetimlerini etki altına alması insan düşüncesine önem kazandırmıştır... Devletin kesin iktidarı dinsel ilkelerle sınırlanınca, bu gelişme insan haklarına olumlu etkiler yapmıştır" (Çeçen 1995: 34). Diğer bir söyleyişle insan, dinin ve dini ilkelerle işleyen devletin katı kararlarının dışında kendine yeni bir düşün ve yaşam alanı aramıştır.

$\mathrm{Bu}$ arayış etrafinda artan birikim Avrupa'da Rönesans ve Reform'un gelişmesine ön ayak olmuştur. Gerek Rönesans'in gerekse Reform’un çekirdeğinde 


\section{Orhan BİNGÖL, "70. Yıldönümünde İnsan Haklarını Yeniden Düşünmek”, \\ Mavi Atlas, 6(Özel Sayı)/2018: 63-76.}

hümanizm yer almaktadır. "Hümanizmin etiğine göre, her şeyden önce insan ile varlığ1 ve çevresi arasında bir bütünleşme kendini gösterir... İnsanın insanlara yararlı olmak için doğduğu düşüncesi ve bu yararlılığın ancak çalışılarak gerçekleşebileceği hümanizmin temel ilkelerindendir" (Çeçen 1995: 43). Buna göre hümanist felsefeyle birlikte Avrupa, kilisenin zorla ve belki farkında olmadan taşırdığı doygunluk eşiğini atlayarak insanı adeta baştan keşfetmiştir. İnsan artık en parlak 1şık kaynağı olarak görülmektedir. Bu aşamada düşüncesi, bedeni veya sanatı üzerinden yeniden yükselen insan, Eski Yunan'ın felsefi referanslarına doğru bir geri dönüşe gitmiştir. Söz konusu dönüşten sıçrayarak geleceğe doğru yapılan atılımlarla sanat, mimari, edebiyat gibi birçok alanda önemli değişimler, yenilikler ve ürünler elde edilmiştir. Rönesans ve Reform'un önünü açtığı bu ilerleyiş asında en insani hakların ve ayrıcalıkların; özgür düşünmenin ve üretmenin kapısını tekrar açarak Avrupa'yı Aydınlanmaya taşımıştır.

Bir felsefe, dönem ya da çağ olarak tanımlanan "Aydınlanma, ...insanın dinsel inanç ve bağl1lığa dair görüşlerden ve bu görüşlerin biçimlendirdiği otorite ve yaşam tarzından kendisini arındırarak akıl ve bilime göre yaşamayı kavramaya, organize etmeye ve yaşamaya çalışması sürecine tekabül etmektedir" (Kızılçelik 2000: 72). Aydınlanma Döneminde insan özellikle bilim ve akıl kanallarında hızlı bir ilerleyiş içine girmiştir. Aydınlanmanın sunduğu bu güzergâhın tamamına akılcılaşma da denmektedir. Akılcılaşma çerçevesinde rasyonel ve bilimsel rotaları kararlılıkla takip eden insan, gerek kendini gerekse toplumu yeni baştan yapılandırmaya girişmiştir.

Aydınlanma Çağıyla hızlanan bu yeni inşada sosyoloji de aktif bir rol üstlenmiştir. Öyle ki sosyolojinin özellikle ilk fikirlerinin olgunlaşması ve temel problemlerinin netleşmesi Aydınlanma Dönemine denk düşmektedir. Örneğin insanın kendini ne gibi yollarla, niçin ve nasıl daha iyi yöneteceği, nasıl bir toplumda yaşatması gerektiği gibi tartışmalar Aydınlanma Döneminin başlıca gündemlerindendir. $\mathrm{Bu}$ çizgide ortaya çıkan çalışmalar, insan hakları açısından insanın özyönetimine ve bunun nasıl siyasallaşacağı meselelerine de değinmektedir. Dönemin en önemli insan hakları temsilcilerinden Jean Jacques Rousseau, toplum sözleşmesini bu dünya görüşüyle üretmiştir. "Özgür doğan insan her yerde zincirlere vurulmuştur" (2013: 7) cümleleriyle başlayan eser, temel olarak ideal siyasal düzeni, ideal hükumetleri, devletin görevlerini ve yeniden kurulacak olan ideal toplumun profilini çizmektedir. Rousseau, kitap boyunca özgürlükten, eşitlikten, demokrasiden ve cumhuriyetten söz etmektedir. İşte Rousseau'nun yazdıkları, insan hakları düşüncesinin Avrupa ve Amerika'daki gelişimine öncülük etmiştir. 1776 Virginia 
İnsan Hakları Bildirisi ile 1789 İnsan ve Yurttaş Hakları Bildirgesi söz konusu gelişmelerin en önemlilerindendir.

Sıçramalı bir gidişle 20. yüzyıla gelindiğindeyse insan haklarıyla ilgili daha ileri adımlar kendini göstermektedir. 10 Aralık 1948'de Birleşmiş Milletler Genel Kurulu'nun ilan ettiği İnsan Hakları Evrensel Bildirgesi ile Avrupa Konseyi'nin 4 Kasım 1950'de imzaladığı Avrupa İnsan Hakları Sözleşmesi bu adımların en gelişmiş versiyonları olarak kabul edilebilir.

Gerek İnsan Hakları Evrensel Bildirgesi gerekse Avrupa İnsan Hakları Sözleşmesi, bugünkü insan haklarının net birer dizilimini içermektedir. Doğumla gelen ayrıcalıkların kaldırılması, yaşama ve özgürlük hakları, mutluluk ve güvenlik arama, bir siyasi topluluk kurma hakk1, mülk edinme ve yasa önünde eşitlik gibi haklar söz konusu maddeler içerisinde başı çekmektedir (Çüçen 2011: 39; Marshall 2003: 11). Dolayısıyla Aydınlanmayla başlayan akılcılaşma sürecine ve yaşam biçimine topluca bakıldığında bunların modern anlamdaki insan haklarını, ekonomik hayatı, hukuku, bürokrasiyi, demokrasiyi, modern devleti ve kapitalizmi var ettiği görülmektedir.

\section{Modern Devlet, Demokrasi, Kapitalizm ve İnsan Hakları}

Modern devlet, insan haklarının özellikle yakın tarihteki gelişiminde kritik bir pozisyondadır. Modern devletin insan haklarıyla olan ilişkileri, genellikle devletin yapısına ve temel fonksiyonlarına eğilmektedir. Bu bakımdan onlarca soru ve münakaşa konusu geçerliliğini halen sürdürmektedir. Örneğin devletin insan haklarını savunma ve geliştirme noktalarındaki gerekliliği nedir? Devlet, insan haklarını gerçekten korumakta mi yoksa ihlal mi etmektedir? Devletin, insan hakları konusundaki hassasiyeti ne kadar gerçektir? Devlet bu konuda ne oranda adil ve eşitlikçi olabilir? Devletler insan hakları hususunda uluslararası gelişmelerden ve konjonktürden kendilerini ne ölçüde izole edebilir?

Polemiklere açık görünen bu tür sorular devlet tabanından yola çıkarak iki farklı elden incelenebilir. "Bunlardan birincisi olumsuz insan haklarıdır ki devletin sakınması gereken şeyler üzerinde durur ve devleti ehlileştirir... İkincisi ise devletin üstlenmesi gereken edimlerdir" (Galtung 1999: 17-18). Bu yaklaşımların ilkine göre modern devlet, insan hakları mevzusunda terbiyeye daima açık haldedir. Devlet, özellikle de hak ihlallerinden kaçınmalı, bu yanlışa düşmemek için sürekli tetikte beklemeli ve kontrol edilmelidir. Diğer açından bakıldığındaysa devletin bu husustaki 


\section{Orhan BİNGÖL, “70. Yıldönümünde İnsan Haklarını Yeniden Düşünmek”, Mavi Atlas, 6(Özel Sayı)/2018: 63-76.}

ödevlerinin başında insan haklarına öncülük etmek gelmektedir. Devlet kendisine müdahale edilmesi bir yana, insan haklarına yönelik aktivitelerinde zorunluluktan çok ödev etiğiyle çalışmalı ve bunu olabildiğince kusursuz yapmalıdır.

Devletin insan hakları konusundaki olumlu veya olumsuz pozisyonlarına değinen bu genellemeleri demokrasi bağlamıyla tartışmak daha doğru görünmektedir. Çünkü bugünkü dünyada demokrasi, birbirinden farklı yapılanmalarda da olsa hemen her modern devleti temelden etkilemektedir. Dünya devletlerinin çoğu demokrasinin karşı çıktıklarından sakınmakta, demokratik ilkelere daima daha yakın olmaya çalışmaktadır. Ayrıca demokrasi insan haklarıyla zaten doğrudan ilgilidir. O nedenle modern devlet ve insan hakları arasındaki etkileşimleri demokrasiyle birbirine bağlamak gerekir.

$\mathrm{Bu}$ noktada özellikle siyasal bir yönetim biçimi olarak alındığında demokrasinin devletin tüm mekanizmalarına ve işleyişine yerleşmiş olması beklenir. O halde modern bir devletin ne kadar demokratik olup olmadığ sadece onu kullanan hükumetlerin başa gelme yollarından ibaret değildir. Devletlerin demokratikliğini tanımlayan şeyler yalnızca bir kurumsal güvenceler bütünlüğü ya da çoğunluğun egemenliğiyle olup bitmemektedir. Modern demokratik bir devlet, her şeyden önce gerek bireylerin gerekse toplumun düşüncelerine, ifade ve eylem özgürlüklerine saygı göstermelidir. Üstelik bu sayg1, devlete ve siyasal iktidarlara nazaran daha az güçlü görünen bireyler ve toplum için zaten bir gerekliliktir. Çünkü güçlüler veya siyasal elitler demokrasi dışındaki birçok rejimde de haklarını elde edebilir (Touraine 2002: 100). Kaldı ki devlet ve toplum ilişkilerinin demokratikliğini yükseltebilmek için topluma öteden beri daha büyük bir ayrıcalık atfedildiği bilinmektedir. Eş deyişle demokrasi, devletin toplumla kurduğu ilişkilerde daima toplumdan yana bir tavır kaydetmiştir. Bunun göstergesi, modern devletin ve siyasetin tarihi gelişiminde açık ve nettir: "Hükümdarların iktidarlarına ve genel olarak siyasal iktidara sınırlamalar getirildiği andan itibaren insan haklarının da ulusal/uluslararası belgelere girdiği görülmektedir" (Tosun 2005: 43).

Söz konusu belgelerde insan(lar)ın özellikle de özgürlük ve eşitlik haklarına sahip çıkıldığı izlenmektedir (Marshall 2003: 291-292; Gündüz ve Gündüz, 2002: 174). Buna göre eşitlik ve özgürlük, devlet ve insan haklarına eğilen uluslararası belgelerin değişmez paydaları içerisindedir. Çünkü özgürlük ve eşitlik ikilisi, devletin topluma karşı demokratik olabilmesinde hem zorunlu gereklilikler hem de devletin yapabileceği potansiyel hak ihlallerini engelleyecek tamponlar gibidir. Böylece 


\section{Orhan BİNGÖL, “70. Yıldönümünde İnsan Haklarını Yeniden Düşünmek”,}

Mavi Atlas, 6(Özel Sayı)/2018: 63-76.

özgürlük ve eşitlik, insan hakları maddeleri ile devletin sosyal ve siyasal siyasal ilkelerinin kaynaşmasında genel harç işlevleri görmektedir. Kısacası, modern demokratik devletlerden eşitlik, insan hakları ve özgürlükler konusunda beklenen erdem, bu haklara saygı duyma ve onların dokunulmazlığına zarar vermeme yönündedir (Çeçen 1995: 70, 73).

$\mathrm{Ne}$ var ki bu doğrultudaki açıklamalar ile şimdinin toplumsal ve siyasal gerçeklikleri arasında keskin bir kontrast söz konusudur. Öyle ki günümüzde çoğu toplum ve devlet insan hakları konusunda genellikle sorunludur. Örneğin TC Adalet Bakanlığı İnsan Hakları Dairesi Başkanlığı'nın yayınladığı Avrupa İnsan Hakları Mahkemesi (AİHM) 2017 Y1lı İstatistik Değerlendirme Notu'na göre Rusya, AİHM tarafından hakkında çıkarılan 293 ihlal kararıyla dünyada birinci sırada yer almaktadır. Sıralamada Rusya'yı Türkiye takip etmektedir. Türkiye, aleyhinde sonuçlanan 99 ihlal kararı ile dünyada insan haklarını en çok ihlal eden ikinci ülke olarak gösterilmektedir. Türkiye'nin ihlal ettiğine karar verilen başlıca insan hakları ise adil yargılanma hakkı, özgürlük ve güvenlik hakkı ile ifade özgürlüğü haklarıdır. Türkiye'den sonra dünyada insan hakları ihlallerindeki üçüncü sırayı Ukrayna almaktadır. Ülke hakkında 82 ihlal kararı çıkmıştır. Yine AİHM 2017 istatistiklerine göre insan haklarını dünyada en az ihlal eden ülkeler ise sırasıyla Fransa, Makedonya ve İspanya'dır.

Söz konusu istatistikler dünyada yaşanan çeşitli insan ihmallerinin ve/veya hak ihlallerinin sadece görünürdeki tabloları gibidir. Ayrıca istatistikler ülkelerin konuyla ilgili kendi içlerindeki gelişmelerini yansıtan sonuçlar olarak okunabilir. Üstelik istatistikler genellikle yüzeyseldir. Günümüz toplumlarının ve devletlerinin, insan haklarına ve demokrasiye dair taşıdıkları problemlerin nedenleri ise temelde yine modern devletlerin yapısını ve uluslararası arenada yaşananları işaret etmektedir.

$\mathrm{Bu}$ noktada insan hakları sorunlarının birçok sebepten kaynaklandığı söylenebilir. Bu sebepler şüphesiz karmaşık haldedir. Ama kapitalizm, insan haklarını bir sorunsala dönüştüren gelişmeleri besleyen kompleks bir çatı olarak öne sürülebilir. Gerçi insan hakları ihlallerinde ilk sıralarda gösterilen Türkiye gibi bazı ülkelerin halen tam olarak kapitalistleșememiş oldukları söylenebilir. Buna göre örneğin Türkiye'nin konuyla ilgili problemleri daha çok kendi siyasal kültürüne ve siyaset tarihine bağlı gibidir. Benzer şekilde, aslında kapitalist olmalarına rağmen insan haklarına karşı hassasiyeti yüksek bulunan ülkeler de yok değildir. 
Ancak bu örnekler, kapitalizm ile insan hakları ihlalleri arasındaki ilişkileri pek zedelememektedir. Çünkü kapitalizm, başta ekonomik ve kaçınılmaz olarak sosyokültürel eşitsizlikler üzerine kurulu yaygın bir sistemdir. Kapitalizm bir yandan ekonomik, sosyal ve siyasal değişkenleri belirleyebilme kapasitesine sahipken öte yandan modern toplumlara, devletlere ve çağdaş dünyaya da damga vurmuş haldedir. Modern toplumlar ve devletler aynı zamanda kapitalistlerdir.

Dünyanın büyük çoğunluğunu saran bu kapitalist yapılanma insan haklarının, özgürlüklerin ve eşitliğin yeterince yaşanıp geliştirilmesine karşı dirençlidir. Çünkü kapitalizm ve demokrasi aslında birbiriyle örtüşmemektedir. Öyle ki “özünde insanın kendi insani amaçlarını özgürce gerçekleştirebilmesi için gerekli bireyci ortamı arayan demokrasi, bu ortamı kapitalist toplumda bulamaz. Kapitalizmde emek ile sermaye birbirinden ayrılmış olup yeterli sermayesi olmayanların kendi insani güçlerini uygulamak ve geliştirmek için gereksindiği özgürlüğü ortadan kaldırılmış, en azından sınırlandırılmıştır” (Köker 1992: 21). Buna göre demokrasinin insani ve hümanist idealleri kapitalizmin ezici realiteleri karşısında zayıf ve yaptırımsız kalmaktadır. Dolayısıyla kapitalizm ile demokrasi arasında asimetrik yapıya sahip prensip, güç ve yaptırım ilişkileri bulunmaktadır.

Üstelik kapitalizmin kapladığı reel dünya ile insan haklarının ve demokrasinin var etmeye çalıştığı ideal dünya arasındaki bu çelişkiler yaşamın birçok alanında kendini göstermektedir. Demokrasinin eşitlikçiliğine ve özgürlükçülügüne karşın kapitalizm, örneğin "kadınlar üzerinde erkeklerin, renkliler üzerinde beyazların, işçiler üzerinde patronların, yurttaşlar üzerinde devlet seçkinlerinin, uluslar üzerinde egemen ulusların sınıf sömürüsünü ilke olarak diğerlerinden daha önemli görmektedir" (Bowles ve Gintis 1996: 21). Dolayısıyla tüm bu nedenlerden ötürü eşitlikler, özgürlükler ve insan hakları çerçevesindeki ulusal ve uluslararası pek çok süreç, kapitalist belirlenimlerin müsaade ettiği kadarıyla gerçekleşmekte, daha doğrusu gerçekleşememektedir. Bugünkü kapitalist dünyada çokça yaşanan insan hakları ihlalleri, bunun en dolaysız göstergeleridir.

\section{Değerlendirme}

İster bir fikir isterse buna dair hazırlanan belgeler açısından olsun insan haklarının temelinde insanın yaşamı, değeri, onuru, özgürlüğü ve eşitliği gibi elzem bileşenler bulunmaktadır. Bu bileşenler insanın bazı seçkin yönlerini tırnak içine almaktadır. İnsan hakları insanın örneğin özgün yanıyla (akıllı ve ahlaklı oluşuyla) yakından ilgilidir. Öyle ki aklının ve ahlakının yardımıyla kendini kasten var edip 


\section{Orhan BİNGÖL, "70. Yıldönümünde İnsan Haklarını Yeniden Düşünmek”, Mavi Atlas, 6(Özel Sayı)/2018: 63-76.}

değiştiren tek canlı insandır. O yüzden insan, kendi haklarının öncelikle oluşturucusu konumundadır.

İnsan aynı zamanda haklarının koruyucusu da olmak zorundadır. Çünkü insan bir toplum içerisinde yaşamaktadır. Toplum, insanın kültürel kimliğini ortaya çıkaran, bunu anlamlı ve sınırlı hale getiren alternatifsiz bir yapıdır. $\mathrm{Bu}$ açıdan insan, haklarının ayırdına ve değerine en çok da toplum içerisinde varmaktadır. Fakat toplumsal hayatla birlikte sosyal yaşama bazı gelişmeler girmekte ve bunları düzene koymaya yönelik birtakım enstrümanlar eklenmektedir. Devlet, siyaset ve demokrasi bu araçların görece en gelişmiş olanlarıdır. Özellikle demokrasi ve demokratik devlet, modern dünyayı, insan hakları yolunda birlikte döndürmeye çalışmaktadır.

Ancak bu yargı en hafif ifadeyle iyimser bir yargıdır. Çünkü insan kendi için bir yandan insan haklarını ve demokrasiyi geliștirmişken diğer taraftan bunlarla uyuşmayan kapitalizmi de üretmiştir. Üstelik özellikle şimdiki durumuna bakılırsa dünya toplumlarını ve devletlerini demokrasiyle yarışır şekilde ve demokrasiye rağmen kapitalizm teslim almış gibidir. Bu bakımdan insan haklarının kâğıt üzerindeki haliyle ekonomik, toplumsal ve siyasal yaşamdaki görüntüleri birbirinden başka haldedir. Dolayısıyla insan hakları, önceden olduğu gibi ilanının 70. Y11 dönümünde de insanın yine kendiyle yüzleşmesinin, mücadelesinin ve çelişmesinin sıkça ihlal edilen bir belgesi olarak yorumlanabilir.

\section{Kaynakça}

BOWLES, Samuel ve Herbert GINTIS (1996). Demokrasi ve Kapitalizm, çev. Osman Akınhay, İstanbul: Ayrıntı Yayınları

ÇEÇEN, Anıl (1995). İnsan Hakları, 2. Basım, Ankara: Gündoğan Yayınları

ÇÜÇEN, Kadir (2011). Insan Hakları, Bursa: MKM Yayıncılık

EROL, Metin (2008). Grup Dinamiği Açısından Türkiye'de Ötekileştirme Ĕgilimleri, Sivas: Cumhuriyet Üniversitesi Yayınları No: 108

GALTUNG, Johan (1999). Bir Başka Açıdan İnsan Hakları, çev. Müge Sözen, İstanbul: Metis Yayınları

GÜNDÜZ, Ferhan ve Mustafa GÜNDÜZ (2002). Yurttaşlık Bilinci, Ankara: Anı Yayınc1lık

HANÇERLİĞLLU, Orhan (1977). Felsefe Ansiklopedisi, Cilt 2, İstanbul: Remzi Kitabevi 
KIZILÇELİK, Sezgin (2000). Frankfurt Okulu (Eleştirel Teori), Ankara: Anı Yayıncilik

KÖKER, Levent (1992). Demokrasi Üzerine Yazllar, Ankara: İmge Kitabevi

MARSHALL, Gordon (2003). Sosyoloji Sözlüğü, çev. Osman Akınhay, Derya Kömürcü, Ankara: Bilim ve Sanat Yayınları

NUTKU, Uluğ (2002).“İnsanın Kültür Varlığı”, CÜ Sosyal Bilimler Dergisi, 26(2): 179-189.

ROUSSEASU, Jean Jack. Toplum Sözleşmesi, 3. Baskı, çev. Ali Alper, İstanbul: Oda Yayınları

SCHOPENHAUER, Arthur (2010) Hukuk, Ahlak ve Siyaset Üzerine, çev. Ahmet Aydoğan, İstanbul: Say Yayınları

TOSUN, Gülgün Erdoğan (2005). "Birleştirici Demokrasi Devlet-Sivil Toplum İlişkisinin Yeniden Yapılandırılması İçin Bir Aracı Olabilir mi?”, Sivil Toplum ve Demokrasi, ed. Lütfi Sunar, İstanbul: Kaknüs Yayınları

TOURAINE, Alain (2002). Demokrasi Nedir?, çev. Olcay Kunal, İstanbul: Yapı Kredi Yayınları

YEŞİLÇAYIR, Celal (2018). “İnsan Haklarının Aydınlatılmasında Felsefi Bilginin Önemi”, Kaygl, 31: 239-261

\section{Online Kaynaklar}

http://inhak.adalet.gov.tr/istatistik/2017/aihm1.pdf 